\title{
Rhizomatic affective spaces and the therapeutic potential of music in prison: a qualitative meta- synthesis
}

\section{Zetta Kougiali, Tomer Einat \& Alison Liebling}

To cite this article: Zetta Kougiali, Tomer Einat \& Alison Liebling (2017): Rhizomatic affective spaces and the therapeutic potential of music in prison: a qualitative meta-synthesis, Qualitative Research in Psychology, DOI: 10.1080/14780887.2017.1359710

To link to this article: http://dx.doi.org/10.1080/14780887.2017.1359710

Accepted author version posted online: 25

Jul 2017.

Submit your article to this journal $\sqsubset$

Q View related articles ¿

View Crossmark data ¿ 


\section{Rhizomatic affective spaces and the therapeutic potential of music in prison: a qualitative meta-synthesis}

\section{Zetta Kougiali, Tomer Einat, and Alison Liebling}

Cambridge University, Institute of Criminology, Cambridge, UK

Zetta Kougiali is now with the University of East London, School of Psychology, London, UK. Tomer Einat is now with Bar-Ilan University, Department of Criminology, Ramat-Gan, Israel.

CONTACT Zetta Kougiali ZKougiali@uel.ac.uk University of East London, School of Psychology, Water Lane, Stratford Campus, London E15 4LZ, UK.

\section{Abstract}

Research literature supports that music programmes in prisons can have a therapeutic effect in prisoners' lives that could promote personal development and assist the process towards desistance. The authors use a meta-synthetic approach to examine 12 qualitative articles published worldwide to explore the therapeutic potential of such programmes. The findings suggest that music programmes in prison are perceived by participating prisoners as a liberating process which encourages participation and allows for non-coercive personal development. The therapeutic potential of music programmes is located in the combination of the benefits emanating from the effect and practice of music and the creation of mental, spatial and temporal zones of free expression and those that derive from the egalitarian and non-authoritative approach employed by the facilitators. These 
findings are discussed along with aspects involved in the provision of offender treatment as well as factors that affect treatment response and engagement.

Keywords, music, prison, offender treatment, offender rehabilitation, meta-synthesis

\section{Introduction}

Research literature indicates that art programmes in prisons have educational, vocational, recreational and psychological benefits, yet such contributions do not constitute 'hard evidence', directly linked with reductions in recidivism. Although past literature reviews on the topic (Hughes, 2005; Johnson, 2008; Meekums \& Daniel, 2011; Cheliotis \& Jordanoska, 2016; Djurichkovic, 2011) have noted several methodological limitations that do not allow for an accurate assessment of the effectiveness of such programmes, there have also been substantial debates underlining the danger of evaluating programmes based on binary questions such as 'whether something works or not', as quasi-experimental designs in criminological research only contribute to the 'nothing works debate' (Pawson \& Tiley, 1994). The influence of positivism in criminological research and the model of desistance as a sudden and not a gradual process have often led to processes and mechanisms - the 'black box' of treatment research (Maruna \& Lebel, 2010) - being overlooked.

The present paper acknowledges that art programmes might be more effective in their contribution towards 'secondary' desistance from crime, by allowing the conditions that enable the desistance process to be created (Cheliotis \& Jordanoska, 2016). Relevant literature reviews have focussed on the overall effectiveness of art programmes in prisons (Hughes, 2005; Johnson, 2008; Meekums \& Daniel, 2011; Cheliotis \& Jordanoska, 2016) and one specifically in visual arts programmes (Djurichkovic, 2011). The above studies follow a similar methodology conducting systematic, or less systematic, literature reviews of arts programmes with offender 
populations. Both qualitative and quantitative studies are being assessed, while most authors note the abundance of anecdotal accounts by therapists and facilitators in comparison to experimental designs. The subjective nature of such accounts, often regarded as a drawback given their restricted value in the collection of data that constitute 'hard evidence', could be invaluable in studies which do not focus on 'whether programmes work or not' but how they do so, examining interaction, processes and personal experiences. Meekums notes (2010: 37): ' Narrative ways of knowing are legitimate and potentially more truthful alternatives to the dominant discourse of scientific positivism'.Based on relevant literature which highlights the therapeutic potential of arts, the aim of this paper is to examine the processes which take place within music programmes, to explore their potential in contributing towards positive change and inquire as to whether there are benefits of including such programmes within the prison system. The methodological limitations and the largely descriptive nature of the existing evaluations of music programmes in prison, issues which will be further addressed below, might constitute a significant restriction towards the identification of measurable effects. Yet, the richness, reflective and expressive nature of data included in evaluations reports, can be used in a constructive way that allows for the acquisition of information on group processes and dynamics contributing, in turn, to the examination of underlying mechanisms involved in programme delivery. In order to achieve this, we employ a meta-synthetic methodology which allows an in depth examination of subjective accounts and a synthetic process of data analysis that could reveal processes and ways such programmes might be having a positive effect. 


\section{The place of arts in prison within the criminal justice system}

Most of the Offender Behaviour Programmes (OPBs) currently employed in prisons have been founded on a strong evidence-base in alignment with the 'What works' literature. The majority of OPBs use methods derived from cognitive social learning theory, aiming at behaviour modification guided by the belief that cognitive, emotional or mental deficits are the source of criminality (Wilson \& Herrnstein, 1985; Yochelson \& Samenow, 1976, 1977). Within a broader framework of over-reliance on risk assessment models, such as the Risk-

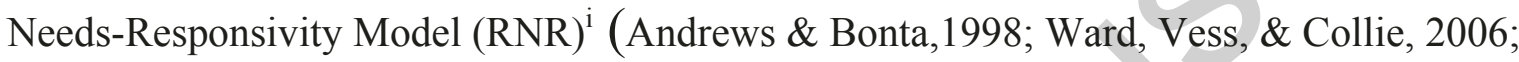
Gannon \& Ward, 2014) investment in treatment programmes is judged on the basis of their cost-effectiveness and the protection they offer to the public (Genders \& Player, 2014). Guided by this approach criminogenic needs, patterns of social interaction strongly associated with the onset and maintenance of delinquency, and specifically the dynamic risk factors (footnote) are prioritised in offender rehabilitation (Andrews \& Bonta, 2010). However, there has been considerable debate as to whether targeting criminogenic needs is an adequate form of intervention when it lacks a broader framework of human motivation (Ward \& Stewart, 2003).

Currently Cognitive behaviour therapy (CBT) based approaches, emphasizing personal accountability and responsibility for criminal offences, outnumber all other therapeutic methods as they are considered the most effective in reducing offending behaviour, (Lipsey, Landenberger, \& Wilson, 2007). The use of CBT as a treatment approach in prison settings has been heavily criticised as a coercive method of attributing responsibility (McKendy, 2006), preventing the creation of an agentic self (Fox, 1999), and 
provoking narratives that are not freely created but are called to fit within provided 'systemic' parameters (Waldram, 2007).

Despite the importance of strong evidence accompanying the delivery of interventions, results on treatment effectiveness have often been marginal (e.g. Cann et al, 2003). It would be inaccurate to make the binary distinction and claim that some programmes 'work' or not in their entirety or to assume a reductionist approach whereby cognitive approaches are ineffective. Methodologically, it has often been argued that assumptions of change (here desistance) as a linear construct, as well as the expectations of a direct causality between treatment and change have led to the predominant use of pre-post measures in evaluation research which cannot always capture or take into account factors that significantly affect personal trajectories of change (Kougiali, Fasulo, Needs, Van Laar, 2017). For example, nonprogrammatic factors $^{1}$ (Palmer, 1995), or assumptions that all participants have the same readiness to change and/or will benefit equally by an intervention, treatment or programme (Friendship, Falshaw \& Beech, 2003), have not been always considered. There is strong evidence that aspects of the therapeutic relationship and style can be of equal - if not of greatest importance - when compared to the content of programmes. Working alliance (McMurran, 2002), trust and 'Rogerian' relational qualities that favour acceptance and openness, for example, can be more effective when compared to authoritative and rigid approaches for individuals involved within the Criminal Justice System (Skeem et al., 2007).

Although art programmes can address risk and protective factors that have been established in the literature as contributing to the reduction of recidivism (Hughes, 2005), there has been limited support and funding for such programmes (Kornfeld, 1997). It can be argued that their distinctive element of 'recreation' as well as their contribution to individual

\footnotetext{
${ }^{1}$ Palmer (1995) lists the following as aspects of successful interventions: 1) staff characteristics: their specific approach, training 2) staff-client interaction as well as skills and ability to form a meaningful relationship, 3) offender characteristics, differences and personality, 4) individualised approach to treatment and 5)setting (community or prison)
} 
expressions, which is essential to our humanity (Liebmann, 1994; Kornfeld, 1997) provide some of the reasons as to why arts in prison can be often overlooked as unnecessary or dismissed as the 'soft option' (The arts Alliance, n.d.). For example, accreditation of offender programmes assessed on the basis "that these programmes are evidence-based and congruent with the 'What Works' literature" (Justice.gov.uk, 2015) - has not been granted to any arts programmes in the $\mathrm{UK}^{\mathrm{ii}}$. Paradigms of penal policies most often reflect political intentions: the provision of an alternative creative and expressive curriculum might not be preferred over programmes which address risk, harm reduction which manage rather than support offenders towards desistance (Clements, 2004).

\section{Art programmes in prison}

Art programmes in prison, including visual art, creative poetry, dance, drama and music are usually offered as part of educational courses delivered by voluntary sector organisations (National Criminal Justice Alliance, N.D.; The Prison Arts Coalition, N.D). Unlike OPBs, art programmes are not designed to target and alter a specific problematic behaviour, such as substance misuse, anger, poor problem-solving skills or violence. Their function is broader and multi-dimensional, constituting an alternative opportunity for participation in programmeswhether educational or not - that could promote personal development and assist the process towards desistance.

Participation in arts programmes has been found to contribute towards improvement in literacy, language and numeracy skills (Hughes, 2005; Miles and Clarke, 2006; Wilson and Logan, 2006; Johnson, 2008; McNeill, Anderson, Colvin, Overy, Sparks \& Tett, 2011; Nugent \& Loucks (2011), advancement in employability skills (McNeill et al. 2011; Ezell and Levy 2003; Harkins, Pritchard, Haskayne, Watson \& Beech, 2011; Cox and Gelsthorpe 2008; De Viggiani, Macintosh and Lang 2010; Uggen, Wakefield and Western 2005) and the development of social 
competence (Gussak 2004; Argue, Bennett and Gussak, 2009). Psychological benefits such as improvement of self-esteem, confidence and self-efficacy (Digard, Grafin von Sponeck, \& Liebling, 2007; Cox \& Gelsthorpe, 2008), cultivation of a sense of collaboration, breaking emotional barriers and mistrust, as well as decreases in levels of anxiety (De Viggiani, Macintosh \& Lang, 2010), have also been noted.

Research literature (for detailed literature reviews see also Hughes 2005; Johnson 2008; Djurichkovich 2011, Cheliotis \& Jordanoska, 2016), suggests that the effects of arts programmes can be both synchronic (at the time of imprisonment) as well as diachronic (developing over time) in terms of their contribution towards desistance. For example, arts can contribute towards the improvement of prison life (Silber, 2010; Menning, 2010), act as an escape route and a way to cope with the pains of imprisonment (Maruna, 2010) but also instil motivation towards 'imagining and embarking on the desistance process' (McNeill, Anderson, Colvin, Overy, Sparks \& Tett, 2011). It has been a matter of debate whether such effects are measurable in terms of 'hard' evidence of reductions in recidivism. Instead, it has been suggested that such contributions take indirect forms that can be best conveyed through the concept of 'secondary desistance' (Cox and Gelsthorpe, 2012; Cheliotis \& Jordanoska, 2016). Yet, 'secondary desistance', the process during which the (ex) offender assumes the role or identity of a changed individual (Maruna, Lebel, Mitchell, Naples, 2004), becomes of primary or secondary conceptual and theoretical value depending on whether the process of abstaining from crime is understood as a linear and sudden or gradual one, as the 'outcome' of termination (Laub and Sampson, 2001: 11) or as a continuous self-reorganisation based on the assumption of new roles. 


\section{Music in prisons}

Prison can be immensely stressful for prisoners, an issue partly related to the composition of the prison population who have often already had a troubled life prior to incarceration (Bensimon., Einat \& Gilboa, 2013; Crewe, 2009). Strain can also be precipitated by the unprivileged, often strict, psychologically demanding and sometimes violent prison environment (Hulley, Liebling, \& Crewe, 2011).

The majority of prisoners come from highly disadvantaged backgrounds (Walsh, 2006). Many are economically deprived or homeless, undereducated or illiterate, chronically underemployed or unemployed, physically and/or mentally unwell and addicted to drugs and/or alcohol (Borzycki \& Baldry, 2003; Dallaire, 2007; Farrington, 2000; Farrington et al., 2006). In addition, upon their admission to prison, many face an anomic, violent, aggressive, crowded, depersonalizing, dehumanizing, and noisy community (Crewe, 2011; Haney, 2006; Lawrence \& Andrews, 2004), as well as various structural deprivations of freedom and autonomy (Marshall, Marshall, Serran, \& O’Brien, 2009; Tangney, 2011). Continuous, often demeaning, trials and adversities can test their tolerance of pain, self-confidence, mental resilience, alertness, and social intelligence (Holman \& Zeidenberg, 2006; Jewkes, 2005; Schnittker \& John, 2007). For such reasons, a number of studies have shown that prisoners suffer from higher levels of mental and emotional distress (e.g. low self-esteem, depression, stress, fear, anxiety, anger, uncertainty and hopelessness regarding their own self and future) in comparison with the general population (Mills \& Kroner, 2005; Samsha, 2005), leading them to act in ways that make them seem less manageable and a greater risk to themselves and others (Grisso, 2008). These behaviours include, amongst others, increased drug abuse, self-harm, and suicide attempts (Liebling, 2007; Palmer \& Connelly, 2005). 
Understanding prisoners' psychological and emotional distress is of paramount concern to where service provision and prison administration are concerned (Buckaloo, Krug \& Nelson, 2009). Consequently, correctional services on both sides of the Atlantic have proposed various coping measures to combat the high levels of stress, anxiety and depression in prison (Howells, Heseltine, Sarre, Davey \& Day, 2004; Lielbing \& Maruna, 2005), heighten the awareness of the outcomes that these emotions can generate (Howells, Watt, Hall \& Baldwin, 1997), and increase the skills of and support for the imprisoned population (Friedmann, Melnick, Jiang \& Hamilton, 2008). Those coping measures include physical fitness (Hilyer \& Mitchell, 1979), recreational activities (Baron \& Richardson, 1994), educational programs (Garland, 1996) and playing music (Daveson \& Edwards, 2001; Hoskyns, 1995).

Art and music-based activities, such as improvisation, allow prisoners to express themselves freely rather than follow strict rules, which can generate a sense of autonomy and responsibility and therefore allow for personal growth and development (Chen et al., 2014; Mossler, 2011). The positive impact of playing music on the welfare, mental and emotional state of various non-incarcerated populations such as clinical and elderly populations (Gardiner, Furois, Tansley \& Morgan, 2000; Labbe, Schmidt, Babin \& Pharr, 2007) has been well established, however the effects of playing music in secure settings on prisoners' quality of life has been studied scarcely (Gold et al. 2014).

\section{Rationale for this study}

\section{METHOD}

The meta-synthetic methodology employed in this paper follows Noblit \& Hare's metaethnographic approach (1988), a methodology which is also applicable to qualitative work beyond ethnography (Britten, Campbell, Pope, Donovan, Morgan \& Pill, 2002; Campbell, 
Pound, Pope, Britten, Pill, Morgan \& Donovan, 2003). Meta-synthetic value does not lie in the mere summary of findings but in the opportunities it provides for the development of theories and methods with a potential for reflection which go beyond (meta) the stage of synthesis (Bondas \& Hall, 2007). Sharing epistemological commonalities with critical realism and interpretevism, the strength of meta-synthesis is situated in the fact that comparing, contrasting and synthesising a larger number of studies can grant access to an underlying reality which is not apparent in the examination of individual articles (Heyman, 2009). Sandelowski \& Barroso note:

"Meta-syntheses are integrations that are more than the sum of parts, in that they offer novel interpretations of findings. These interpretations will not be found in any one research report but, rather, are inferences derived from taking all of the reports in a sample as a whole." (Sandelowski \& Barroso, 2003 as quoted in Thorne, Jensen, Kearney, Noblit \& Sandelowski, 2004:1358).

The process followed in the present study was based on Noblit \& Hare's iterative research process and consisted in the following steps: 1) identification of the specific area of study, 2) deciding which study fulfils the inclusion criteria and determine what is relevant, 3) reading the studies in order to locate potential themes, 4) determining how the studies are related, 5) translating/comparing studies/themes with each other, 6) synthesising translations/findings and 7) expressing/reporting findings.

\section{Search strategy}

This paper was not intended as an exhaustive review of all literature on arts programmes, as this has been the objective of previous work on the subject (Hughes, 2005; Johnson, 2008; Meekums \& Daniel, 2011; Cheliotis \& Jordanoska, 2016; Djurichkovic, 2011). We have chosen to assess the therapeutic potential of music in prisons, based on the evidence indicating the potential of such programmes. 
In order to examine the therapeutic benefits of music stripped from the influence of any structured treatment approach, studies that were examining music therapy were excluded. Instead, we focused on studies that were evaluating music programmes in prisons and included teaching of at least one musical instrument. Arts and music as a general concept include numerous styles and forms of expressions which influence the ethos and content of programmes. For this reason, and in order to eliminate various 'methodological noises', apart from excluding therapy focussed interventions, we focussed on pure instrumental music playing. The study included all topic-specific English research literature published until 2016. We searched standard bibliographical databases such as Google Scholar, PubMed, PsychINFO, Web of Knowledge, EBSCO. Keywords such as 'music + prison', 'music+offenders' or words isolating specific musical instruments such as 'drums+prison', 'gamelan+prison' were used in order to perform a thorough search of the databases. In order to locate the full number of studies that have been conducted so far, the search was expanded and we hand-searched book chapters and journals, examined references in detail, and located unofficial records as well as grey literature.

\section{Quality assessment}

The potential of qualitative research to inform policy and practice by answering questions that can be mostly examined qualitatively, such as investigating the 'how' programmes work (Campbell et al., 2003; Davies, 1999; Newman, Thompson, Roberts, 2006; Popay, Roberts, Sowden, Petticrew, Arai, Rodgers \& Duffy, 2006) has been well established. However, there has been a significant debate surrounding the challenge of synthesising qualitative literature, as it is an often more complex and demanding task than attempting to include exclusively Randomised Controlled Trials (Thomas \& Harden, 2008). Apart from the methodological variation, including studies that have employed different approaches might present a risk of including and interpreting work of differing quality which might distort the findings of a review (Dixon-Woods \& Fitzpatrick, 2001; Dixon-Woods, Shaw, Agarwal \& Smith, 2004). 
The methodological quality of the papers located for the purposes of the present study varied considerably. The search revealed an almost complete absence of peer-reviewed articles which were outnumbered by independent programme evaluations. The evaluations suffered from methodological inconsistencies ranging from weak research designs, poor or non-existent analyses, often leading to dubious findings- especially in the case of organisations that were selfevaluating their own programmes.

For the reasons above, the methodological quality of each paper was assessed separately using criteria based on CASP (Critical Appraisal Skills Programme) as well as the criteria outlined by Popay et al. (2006) (the full proforma is available from the corresponding author). Both tools were created for the purpose of assessing the quality of qualitative research by addressing several areas such as research design, analysis, appropriate samples and generalisability. Each paper was assessed by two members of the research team while consensus was discussed following independent rating. The initial search revealed 31 results and the number of studies that fulfilled both the inclusion as well as the quality criteria was reduced to 12 after the quality assessment process (see Table 1 for a full list of included studies).

The studies analysed in this paper were predominantly programme evaluations, conducted within various prison establishments and a single follow-up study conducted in the community. Their methodology was either mixed or qualitative, with rich reflective and ethnographic material, which offered a detailed account of the processes that took place within the music groups. In cases of mixed methodology and for the purposes of this study, only the qualitative part of the studies was analysed. 


\section{Analysis}

Quality assessment as well as data analysis was initially conducted independently and was later compared, discussed and reflected upon within the research group.

We conducted a thematic analysis of all the articles which was assisted by the use of Nvivo 10 software. The analysis was conducted in a way that exceeded the collection and summation of common themes across the studies, but rather implemented a 'reciprocal' translation. According to Noblit \& Hare, the understanding of two studies is enhanced when these are compared and translated, as they are not examined merely as two independent or disjoined units but are better understood 'in terms of each other', contributing to a common dialectical - understanding of the area (1998:47). Apart from the themes which were already identified by the authors of each paper, considerable attention was given to the data and participants' quotes, as they highlighted underlying mechanisms and processes that took place in every case.

\section{Findings}

The findings indicated that although music appeared to have positive psychological effects, the overall therapeutic benefits of the programmes did not originate from music alone. Music acted as a channel through which participants felt more capable of forming trusting relationships with the facilitators and with members of the group. This was initially facilitated and further sustained by the collaborative culture inherent in the taught music genres which shaped the instructors' approach. Elements of trust, safety, the non-authoritative nature of the programmes as well as their significant differences from other programmes delivered in prison settings, were highlighted by prisoners. 
The analysis, translation and synthesis of the included studies resulted in two themes which support the therapeutic potential of music programmes in prison: 1) the therapeutic effects of music and 2) therapeutic processes within groups.

\section{Therapeutic effects of music}

The therapeutic effects of music, as mentioned throughout the reviewed studies consisted in the beneficial effects of music alone (1.1) as well as when music was referred to as performance and activity (1.2).

\section{1. $\quad$ Rhizomatic affective spaces}

The most frequently mentioned direct and identifiable effect of music was the fact that after its introduction, it became essential in surviving the pains of imprisonment and giving meaning to a bleak and mundane daily routine:

In terms of living - surviving the prison experience - music has been absolutely essential. I could not have done it without music. I mean, I would have just shrivelled up and died, I think' (De Viggiani, Macintosh \& Lang, 2010: 63)

The above quote illustrates graphically how the prison experience and existence within prison was perceived before music was introduced to the prisoner's life. The verb 'shrivel' depicts a gradually narrowing existence, losing vigour and vitality, being steadily reduced to a metaphorical, perhaps, psychological or spiritual death. Music, in this case, was 'essential' in dealing with the debilitating effects of the prison experience.

Similarly, in the quote below, a prisoner uses a spatial metaphor to describe how music interrupted the 'horror' of prison and enabled the passage from a state of being physically confined and emotionally unable to advance ('trapped') towards a psychological elevation ('lifts you') accompanied with progression and adoption of a more hopeful perspective: 
'It was an incredible break from such a horror. Being trapped in here with no way of moving on. It lifts you and gives you perspective.' (Henley, 2012:35)

Although the mechanism through which music contributes to the alleviation of stress and pain is not always clear, it has been argued that music can function as a distraction, enabling individuals to focus on something soothing, positive and pleasant, enabling an 'escape into their own world' (Staum \& Bottoms, 2000; White, 2001). The metaphors used by the participants indicate that music might be operating in a way that disrupts the prison experience and creates affective spaces where prisoners can escape to and use as a way to cope and regain hope before returning to their everyday routine. Being distinct from the ordinary reality yet highly connected and informing the emotional experience of being in prison, the characteristics of such spaces are analogous to the concept of the 'rhizome' developed by Deleuze and Guattari whereby:

'The rhizome connects any point to any other point, and its traits are not necessarily linked to traits of the same nature; it brings into play very different regimes of signs, even nonsign states (...) It is composed not of units but of dimensions, or rather directions in motion. It has neither beginning nor end, but always a middle (milieu) from which it grows and which it overspills (Deleuze and Guattari, 1987: 21).

Music, in this context, activates rhizomatic affective spaces in prison which would function as expressions of transcendent ends experienced both as detachable - whereby prisoners can mentally escape- but also connectable in the way they positively altered and made the prison experience more tolerable:

"when I play the drums, it is like I am dreaming, floating away". (Cox \& Gelsthorpe, 2008)

Music enables the experience of 'transcedence' to rzhiomatic spaces where mental reality appears to be spatially but also temporally nullifying, thus reducing the time actively 
spent 'in prison'. Consecutively, the lack of music as a disruption of the daily routine appears to extend the passage of time:

Unless you play, it's impossible to understand what it means - that sense of freedom you experience - It doesn't make any difference where I am at the time ... When I came back to prison and they wouldn't let me have my guitar for a month, it was a nightmare. A month felt like a year. '(De Viggiani, Mackintosh \& Lang, 2010:64)

The term rhizomatic (or rhizomatic growth) in research, learning or experience means non-hierarchical, multiple, complex and non-linear, with ceaseless and shifting connections, attractions, meanings and influences. This reflects the kinds of processes described by participants in arts and other (for example literature-based) growth-oriented programmes, as well as the kinds of goals such programmes embody. They are both stretching and remedial, or healing.

A participant from HMP Wandsworth, quoted in Cox \& Gelsthorpe (2008), explains how music allows prisoners to release emotions that are usually either being 'bottled up' and kept hidden both from peers and staff or expressed in negative forms:

"It helps people relax. Takes the stress out of their mind. Lets them release their emotions. Especially in here where it's all bottled up. I'm sure there would be less fights because when you come out you feel calm. You've mellowed out and you don't want to get into trouble" (820: 31).

The notion of escape through music was expressed in similar quotes either in terms of a positive psychological transference or, more actively, as a means through which prisoners could express their feelings and alleviate the stress caused by an overwhelming captive experience. In such cases, music itself but also the social environment in which it was practiced was experienced as a separate social sphere, an outlet in which emotional distress could be channeled and alleviated. 
Agentic individualism versus passive criminality

As opposed to programmes based on teacher-centered approaches, practicing music and being creative had noticeable effects on self-perception and individual identity.

In the vast majority of the studies, participants referred to other programmes offered in prison highlighting both the fact that these were not tailored to their needs and mentioning issues such as the difficulty of engaging and the passive role of participating prisoners:

'They would rather try and teach mathematics to people who don't want to learn, put them on a course that they won't attend - which is a total waste of money. You've got a teacher sitting there with two people instead of ten! Whereas, if you put guitar lessons on, you might get ten people to attend. '( De Viggiani, Mackintosh \& Lang, 2010:58)

The prisoner above addresses several issues such as programmes not tailored to participants' characteristics, low attendance and interest levels as well as the difficultly of encouraging prisoners to engage with traditional educational programmes (see also Belzer, 2004; Maclachlan, Hall, Tett, Crowther and Edwards, 2008; Tett, Anderson, McNeill, Overy, \& Sparks, 2012). Programmes offered in prison were often criticised for encouraging passive participation, sustaining the 'criminal' label and undermining individual competence, skills and potential for personal growth. Music programmes appeared to differ in the way they cultivated and supported a responsible, proactive self, capable of achieving and developing:

'Generally in prison, you are treated as an idiot. The courses are pitched to the very lowest level the prison authorities perceive. I'm on a course at the moment-a transition course -I sit there thinking, 'For God's sake, say something meaningful!', whereas this course really challenges you and makes you think - It's made me have to take some risks by taking part and to act in an adult way. '( De Viggiani, Mackintosh \& Lang, 2010:57) 
Considering that prison is a 'marginal situation' (Berger \& Luckmann, 1991) whereby the normality of everyday life is disrupted, it can be argued that demarcation of one's selfperception and identity from the one assumed by penal practices constitutes a complex endeavour. Deficit focussed approaches that utilise the 'criminal identity' often do so in order to instil responsibility for past actions, yet it is unlikely that such labels contribute to personal development or facilitate the process of desistance. On the other hand, expectations of a better future self can instil greater self-belief, and self-confidence, as well as the adoption of the behavioural and practical ways to achieve these (Maruna et al., 2004).

The program helped me to think of myself as a musician and artisan... it also helped me to begin feeling normal again. The system just beats you down; the humiliation of being a convict is indescribable. 'Arts in Corrections' was like a breath of normalcy and it helped me to regain my self-respect (Brewster, 2010:38)

Labelling practices were contested by participants in the majority of the studies, while many noted that participation in music programmes contributed to the restoration of a sense of normality and assisted in envisioning a different, proactive and future-focused version of self.

\section{Therapeutic processes within music groups}

The therapeutic processes reported in the studies analysed in this paper should be considered alongside the effects music had on prisoners. The recreational element of music acted as an incentive for initial participation but the perception of music programmes as 'emotional zones' (Crewe, Warr, Bennett \& Smith, 2013) where free expression was permitted, set the foundations for the development of a safe environment. The absence of any obligation for participation as well as the approach employed by the instructors resulted in programmes which could be characterised as having a 'more rehabilitative rather deterrent' nature (Maruna, 2010: 4). 


\subsection{Group climate and therapeutic alliance}

It is important to note here that the smooth progress of a group cannot be predicted accurately as it is heavily dependent on the dynamic interaction between the participating members and the facilitator. Hill \& Harris (2011: 16) note: "any 'factor' or 'process' that arises in a group has the power to be positive (and therefore therapeutic and curative) or negative (and therefore counter-therapeutic)." Initial disruptions were frequently reported and occurred until the groups negotiated a common code of communication . The resolution of the participants' initial ambivalence appeared to be achieved through the approach employed by the instructors and, perhaps, the comparison with the most often encountered punitive tactics.

Group climate and, specifically, the instructors' approach were consistently reported as being non-directive, non-authoritative, non-judgmental, encouraging creativity rather than employing a unidirectional teacher-centered approach. The absence of imposition, the active engagement of the prisoners and the non-didactic style of the instructors, led to the cultivation of a 'team spirit', while prisoners commented that 'it rarely felt like you were being taught (Digard, von Sponeck \& Liebling, 2007:3). It is worth mentioning here that the prevalent culture in certain kinds of music playing, such as gamelan, is communal and egalitarian. Such culture attributes no leading role to the instructor, cooperation is emphasised and every player is of equal importance (Eastburn, 2003).

The non-authoritative and democratic approach enabled the development of a working alliance between the prisoners and the instructors, allowed for members of the group to bond and set the basis for the creation of a safe environment where prisoners could express their feelings freely:

'The tutor cultivated a very healthy climate of mutual respect, consideration and fairness, in which I felt totally comfortable and at ease in every respect in every session, to participate as much or as little as I wanted.' (Maruna, 2010: 10). 
Trust, honesty, respect and safety were not established immediately, as expected in any form of group work and especially one that takes place in secure settings. The participants, initially cautious, went through several stages before groups could work effectively together. During the initial group sessions participants appeared to be transferring their own behaviour to the group, often by being controlling, disruptive or subduing. In several cases some members wondered if they were 'allowed to say how they felt', but the gradual recognition of the music group as a safe environment helped both reticent and more boisterous personalities to take risks (Digard et al., 2007). Such risks were perceived in terms of emotional expression, whereby participants who did not feel particularly comfortable in expressing their feelings, were vulnerable, or had experiences of past abuse, managed to take a step forward and trust the other members. Performing in front of an audience was also identified as a form of vulnerability often entailing expectations of being criticised or even rejected, especially for participants with low confidence. Taking risks, being vulnerable in front of others and overcoming these feelings led, in turn, to a sense of pride and achievement. This served as a confidence booster and allowed participants to feel accepted and able to express their vulnerabilities. As one of the participants in Digard et al, 2007 notes:

‘just being ourselves really (...) everyone puts up a shield, don't they, and I think that shield was let down by every single one of us'.

Within a climate that favoured open expression of feelings prisoners sought group membership, engaged actively, worked together and contributed equally in the music outcomes. Being part of the "we", as opposed to the more frequently met "them and us" attributions in prison, prisoners often described the ability to express ideas and interact on equal terms as a representation of a form of freedom, rarely experienced but highly valued in prison settings. As noted in Maruna (2010): 
A good social network arose out of the music-mutually supportive in [the] prison setting."

"It got people working as one, which is usually very difficult to do in prison."

The different life experiences of the group members, the variation in the levels of music knowledge, yet the collective effort to perform music as a group, created a sense of mutual support and 'togetherness'. The effort to perform, gradually created strong bonds between the members of the group, as well as strong friendships between individuals who would not have chosen to collaborate, or even interact with each other.

\subsection{Identity and future self}

The way individuals perceive, discuss and position themselves has been suggested as being an important element in desistance from crime (Giordano, Cernkovich \& Rudolph 2002; Maruna, 2001). Individual concepts about future selves (Markus \& Nurius, 1986), the projection of hopes, fears, and aspirations of how one might become in the future but also what one wishes or is afraid of becoming might indicate changes in self-perception but can equally initiate action towards achieving a desired or avoiding an unwanted version of one's self.

Although in most of the studies analysed in this paper relevant quotes appeared under assessments linked with employability skills, there were obvious differentiations in selfperceptions that could indicate subtle, or more significant, identity changes. A prisoner in Brewster's (2010) study envisioned himself 'as a musician and artisan' and similarly the participant below presents a projected hypothetical (when/if) version of himself as a college applicant giving evidence (show/it shows) on his past experience and competencies both in education and in personal development: 
I think when I get out if I go to college and show that I've been doing music in here it shows that I'm able to get my head down and work. I'm not just going to work. I'm doing education as well. So, it shows that I'm willing to work and I'm trying to better myself.'(Anderson \& Overy, 2010:56)

Active learning, creativity and the sense of achievement were presented as contradictory to participants' self-concept as cultivated so far within prison and were often mentioned along with new self-evaluations and explanations of past behaviours:

'In prison you feel worthless, so act ignorant and defensive, but when doing something useful, you feel valued, so act differently. "(Maruna, 2010:19)

When you start to achieve in something, you start saying to yourself, 'carry on achieving and achieving and achieving'. '(De Viggiani et al., 2010:68)

In view of negative self-perceptions expressed throughout the reviewed papers, often facilitated by the negative prison climate, experience and treatment, it is worth noting references to agency and autonomy. Such references often had a comparative note, contrasting an old, perhaps 'lost self' with a new version of one who is 'a person' and 'an individual' rather than a prisoner or a criminal:

"It gave me a chance to be an individual.." (819:22)

"It's like, for a couple of hours you're not in prison. You might have turned up at a village hall somewhere out in the community. For that small space of time, you are treated like a person rather than a prisoner."

Charmaz (1983:170) defines self-concept as the 'organisation of attributes that have become consistent over time'. Maintaining organisation of the self requires 'empirical validation in daily life' (Ibid). It has been argued that prison can undermine autonomy and self-initiative, especially amongst those who have been imprisoned for long periods of time or who have been 
frequently placed in solitary confinement, often leading to beliefs that life is controlled by 'powerful others (Haney, 2003; Taylor, 1961; Scraton, 2016). Feelings of 'worthlessness' and 'uselessness' as quoted above, could consolidate a negative and non-proactive view of self and facilitate withdrawal from the prison world or from activities. On the contrary, positive outcomes in secure settings are linked to a social climate of high support, opportunities for the exercise of autonomy, an ordered environment and the absence of obtrusive staff control (Timko \& Moos, 1998, Einat, 2004, Liebling, 2007).

\section{$\underline{\text { Discussion }}$}

The analysis conducted for the purposes of the present paper suggests that music programmes in prison are perceived by participating prisoners as a liberating process which encourages participation and allows for non-coercive personal development. Such programmes are not presented as an attempt by the 'system' to induce or force personal change but as something that is offered as an opportunity, distinct from traditional forms of treatment or education.

The therapeutic potential of music programmes is located in the combination of the benefits emanating from the effect and practice of music and the creation of mental, spatial and temporal zones of free expression and those that derive from the egalitarian and nonauthoritative approach employed by the facilitators. These findings are important when considering several aspects of the provision of offender treatment, such as the significance of 'safe spaces' for personal development, the contextual factors affecting treatment response and engagement, as well as the importance of non-programmatic factors.

The findings indicate that active and voluntary participation of prisoners in music programmes in prison is related to feelings of satisfaction, achievement and empowerment. 
Frankel (2000) argued that two inherent aspirations of all individuals are to find a meaning for their lives and to fulfil their hidden potential through, among other things, achievements that are experienced as meaningful and satisfactory. Such experiences are therapeutically validated in cases where individuals emerge from their own egocentricity and invest energy and efforts in targets considered exalted and positive (Frankel, 1963). In other words, the unrestricted, favourable and non-authoritative approach employed by the facilitators combined with the prisoners' investment of energy and effort in positive and challenging prosocial activities, assists the latter in finding existential meaning to their lives. Hence, it can be suggested that there would be considerable value in the expansion and support of music programmes within prison settings as these can actively include prisoners and allow them to engage in meaningful personal challenges.

When discussing processes involved in most form of human experience, we recognise the dynamic interaction of spatial, temporal and (inter)personal factors in their fluid intersection, which depends on the interplay of contextual and personal factors. In an effort to improve treatment provision and services there is often a danger of isolating or attempting to intervene by targeting solely either individual (e.g. personality traits and behaviour) or environmental (e.g. peers and family) elements of human experience. However, there is an interdependence of psychological and spatial dimensions or 'something psychological in the spatial and vice versa' (McGrath, Reavey, Brown, 2008) and our analysis identified two levels of interconnectedness between the 'spatial' and the 'therapeutic'. Previous research has suggested the existence of 'emotion zones' in prisons whereby emotional display may vary (Crewe et al., 2013) and has observed that prisoners' agency can be found in their ability to "make their own spaces, material and imagined" (Sibley and van Hoven 2009: 205). Our findings suggest that music can facilitate the emergence of rhizomatic affective spaces which can disrupt, temporally and spatially the pains of imprisonment. The non-authoritative and egalitarian approach employed by the 
instructors, central in some forms of music cultures, enabled the development of socially safe spaces within music groups and promoted autonomy and the conceptualisation of an agentic self.

The there are numerous obstacles in offender engagement within group programmes has been well established in the literature. Recent research suggests that greater treatment gains can be achieved through non-confrontational approaches and active participation (Entwistle and Smith, 2002; Hurry, Brazier \& Wilson, 2009; Crowther, Maclachlan and Tett, 2010; Holdsworth, Bowen, Brown \& Howat, 2014). The findings of this study suggest that when individuals perceive themselves as the subjects of others' efforts to alter and 'correct' them, they are automatically positioned in the role of the receiver, which prevents any invocation of agency. It has been well argued in literature concerning therapeutic programmes that contextual factors, or 'conditions', have received far less attention when compared to therapeutic techniques (Hazler \& Barwick, 2001; Liebling, assisted by Arnold 2004). In this paper, we argue for the importance of such contextual and non-programmatic factors (Palmer, 1995) towards positive psychological but also educational programme outcomes. The practical implementation of a climate of active participation which could reduce the power differential between practitioners and prisoners and promote agency resonates with Freire's democratic pedagogical approach whereby the (1) teacher acts as facilitator, (2) musical knowledge is perceived as creative self-expression, (3) the classroom is community and (4) performance is action (see Shieh, 2010).

An additional significant outcome of this study relates to the positive and constructive effect of the role of the facilitator on the relationship between practitioners and prisoners. In contrast to most relationships between prisoners and prison staff, which are often characterized by authority, suspicion and lack of trust (Crewe 2005; Liebling assisted by Arnold 2004), the interaction between facilitators and prisoners is based on an a priori delegation of authority. Moreover, due to the unrestricted, favourable and non-authoritative approach employed by the facilitators, the prisoners' active participation (e.g. playing music, raising comments, encouraging 
and assisting their counterparts) in the programme is considered essential to its success. It therefore seems that a relationship characterized by reciprocity, trust, professional appreciation, equality and a high level of democratization, undermines the traditional balance of power between staff and prisoners and reduces the social distance between them. This reflects some desirable trends in the fields of penology and prison management (Liebling and Price 2001; Tait, 2012) which pertain to the direct connection between leading the prison administration through an intelligent use of soft power (Crewe 2011), reducing negative and stereotypical perceptions and the feelings of hostility, anger, and frustration on the part of the prisoners while promoting trust and respect between prisoners and staff (Hulley, Liebling, and Crewe 2011). It is therefore recommended that correctional facilities increase the number of arts programmes in general - and music programmes in particular - requiring cooperation between prisoners and staff. Such policy would potentially contribute to both group members to adopting expressions of mutual respect, concern, equality, appreciation and trust.

In this paper we highlight the therapeutic effects of music as a coping mechanism and suggest that democratic and inclusive approaches as well as active participation in music could be used as a way to increase offenders' engagement with OPBs, but more important as a means of self-development. Music and, in turn, artistic programmes, despite their potential contribution toward desistance do not have a prominent place in prison, perhaps because the recreational element does not align with current risk management and 'public acceptability' approaches to prison regimes. However, programmes that break the 'us and them' barrier, and create safe spaces of emotional expression, should be 'judged on their own terms' (Phillips, 1996), and should be used alongside and to complement the existing service provision within secure settings.

Finally, it can be argued that qualitative work on systematic reviews is a method that should be also 'judged in its own terms' (ibid), as the epistemological aims and outcomes are 
substantially and qualitatively different from methods which are evaluating whether something ‘is’ effective or not. Meta-synthetic methodologies firstly allow researchers to access key information, such as contextual factors, processes and subjective experiences -the 'how' of whether programmes work - and enable the synthesis of information, found in sources such as grey literature or programme evaluation, which can produce valuable knowledge which is non accessible or dismissed in other methodologies.

\section{References}

Anderson, K., \& Overy, K. (2010). Engaging Scottish young offenders in education through music and art. International Journal of Community Music, 3(1), 47-64.

Argue, J., Bennett, J. and Gussak, D. (2009) 'Transformation through negotiation: Initiating the Inmate Mural Arts Program', The Arts in Psychotherapy, 36, 313-319.

Baron, R., \& Richardson, D. (1994). Human aggression (2 ${ }^{\text {nd }}$ edition). New York, NY: Plenum.

Belzer A. (2004) "Not like normal school": The role of prior learning contexts in adult learning', Adult Education Quarterly, 55, 41-59. DOI: 10.1177/0741713604268893.

Bensimon, M., Einat, T., \& Gilboa, A. (2013). The impact of relaxing music on prisoners' levels of anxiety and anger. International journal of offender therapy and comparative criminology, $0306624 X 13511587$.

Berger, P. L., \& Luckmann, T. (1991). The social construction of reality: A treatise in the sociology of knowledge (No. 10). Penguin UK.

Borzycki, M., \& Baldry, E. (2003). Promoting integration: The provision of prisoner post-release service. Canberra, Australia: Australian Institute of Criminology. 
Bondas, T., \& Hall, E. O. C. (2007). Challenges in Approaching Metasynthesis Research.

Qualitative Health Research, 17(1), 113-121. doi: 10.1177/1049732306295879

Brewster, L. (2010). The California arts-in-corrections music programme: A qualitative study. International Journal of Community Music, 3(1), 33-46.

Britten, N., Campbell, R., Pope, C., Donovan, J., Morgan, M., \& Pill, R. (2002). Using meta ethnography to synthesise qualitative research: a worked example. Journal of health services research \& policy, 7(4), 209-215.

Buckaloo, B. J., Krug, K., \& Nelson, K. (2009). Exercise and the low security inmate: Changes in depression, stress, and anxiety. The Prison Journal, 89, 328-343.

Burrowes, N., Disley, E., Liddle, M., Maguire, M., Rubin, J., Taylor, J., \& Wright, S. (2013). Intermediate outcomes of arts projects: a rapid evidence assessment. Analytical Summary.

Campbell, R., Pound, P., Pope, C., Britten, N., Pill, R., Morgan, M., \& Donovan, J. (2003).

Evaluating meta-ethnography: a synthesis of qualitative research on lay experiences of diabetes and diabetes care. Social science \& medicine, 56(4), 671-684.

Critical Appraisal Skills Programme (n.d.). Retrieved on 5 May, 2014 from http://www.caspuk.net/casp-tools-checklists

Charmaz, K. (1983). Loss of self: a fundamental form of suffering in the chronically ill. Sociology of health \& illness, 5(2), 168-195.

Cheliotis, L., \& Jordanoska, A. (2016). The arts of desistance: Assessing the role of arts-based programmes in reducing reoffending. The Howard Journal of Crime and Justice.

Clements, P. (2004). The Rehabilitative Role of Arts Education in Prison: Accommodation or Enlightenment? International Journal of Art \& Design Education, 23(2), 169-178. doi: $10.1111 /$ j.1476-8070.2004.00395.x

Cox, A., \& Gelsthorpe, L. (2008). Beats \& bars. Music in prisons: An evaluation. London: The Irene Taylor Trust. 
Crewe, B. (2005). Codes and Conventions: The Terms and Conditions of Contemporary Inmate Values. In: A. Liebling \& S. Maruna (eds.), The Effects of Imprisonment (pp. 177-208). Cullompton: Willan Publishing.

Crewe, B. 2009. The prisoner society. Power, adaptation and social life in an English prison, Oxford: Oxford University Press.

Crewe, B. (2011). Depth, weight, tightness: Revisiting the pains of imprisonment. Punishment and Society, 13, 509-529.

Crewe, B., Warr, J., Bennett, P., \& Smith, A. (2013). The emotional geography of prison life. Theoretical Criminology, 1362480613497778.

Crowther, J., Maclachlan, K., \& Tett, L. (2010). Adult literacy, learning identities and pedagogic practice. International Journal of Lifelong Education, 29(6), 651-664.

Dallaire, D. H. (2007). Incarcerated mothers and fathers: A comparison of risks for children and families. Family Relations, 56, 440-453.

Daveson, B., \& Edwards, J. (2001). A descriptive study exploring the role of music therapy in prisons. The Arts in Psychotherapy, 28, 137-141.

Davies, P. (1999). What is evidence-based education?. British journal of educational studies, $47(2), 108-121$.

Deleuze, G. and Guattari, F., 1987. A Thousand Plateaus. Minneapolis: The University of Minnesota Press.

De Viggiani, N., Macintosh, S., \& Lang, P. (2010). Music in time: An evaluation of a participatory creative music programme for older prisoners.

Digard, L., von Sponeck, A. G., \& Liebling, A. (2007). All together now: the therapeutic potential of a prison based music programme. Prison Service Journal, 170, 3. 
Dixon-Woods, M., Fitzpatrick, R., \& Roberts, K. (2001). Including qualitative research in systematic reviews: opportunities and problems. Journal of evaluation in clinical practice, $7(2)$, 125-133.

Dixon-Woods, M., Shaw, R. L., Agarwal, S., \& Smith, J. A. (2004). The problem of appraising qualitative research. Quality and Safety in Health Care, 13(3), 223-225.

Djurichkovic, A. (2011) 'Art in Prisons: A Literature Review of the Philosophies and Impacts of Visual Art Programs for Correctional Populations', Report for Art Access Australia, UTS Shopfront Student Series, No 3, Broadway: Art Access Australia.

Eastburn, C. 2003. Gongs behind bars: Evaluation report of the Good Vibrations Gamelan in Prisons pilot project 2003, Wellingore: The Firebird Trust.

Einat, T. (2004). Criminal Fine Enforcement in Israel Administration, Policy, Evaluation and Recommendations. Punishment \& Society, 6(2), 175-194.

Einat, T. (2015). The Wounded Healer: Self-Rehabilitation of Prisoners through Providing Care and Support to Physically and Mentally Challenged Inmates. Journal of Crime and Justice. DOI: $10.1080 / 0735648 x .2015 .1095647$.

Entwistle, N., \& Smith, C. (2002) 'Personal understanding and target understanding: mapping influences on the outcomes of learning', British Journal of Educational Psychology, 72(3), $321-342$.

Ezell, M., \& Levy, M. (2003). An evaluation of an arts program for incarcerated juvenile offenders. Journal of Correctional Education, 108-114.

Frankel, V. E. 1963. Man's Search for Meaning. New York: Simon and Schuster.

Frankel, V. E. 2000. Man's Search for Ultimate Meaning. Cambridge, MA: Perseus Publishing. 
Friedmann, P., Melnick, G., Jiang, L., \& Hamilton, Z. (2008). Violent and disruptive behaviour among drug-involved prisoners: Relationship with psychiatric symptoms. Behavioral Sciences \& the Law, 26(4), 389-401.

Gardiner, J. C., Furois, M., Tansley, D. P., \& Morgan, B. (2000). Music therapy and reading as intervention strategies for disruptive behaviour in Dementia. Clinical Gerontologist, 22, 3146.

Garland, D. (1996). The limits of the sovereign state. British Journal of Criminology, 36, 445471.

Giordano, P. C., Cernkovich, S. A., \& Rudolph, J. L. (2002). Gender, crime, and desistance: Toward a theory of cognitive transformation1. American journal of sociology, 107(4), 9901064.

Gold, C., Assmus, J., Hjornevik, K., Qvale, L., Brown, F., Hansen, A., Waage, L., \& Stige, B. (2014). Music therapy for prisoners: Pilot randomized controlled trial and implications for evaluating psychosocial interventions. International Journal of Offender Therapy and Comparative Criminology, 58(12), 1520-1539.

Grisso, T. (2008). Adolescent offenders with mental disorders. Future of Children, 18, 144-164.

Gussak, D. (2004). Art therapy with prison inmates: A pilot study. The Arts in Psychotherapy, 31, 245-259. doi:10.1016/j.aip.2004.06.001

Haney, C. (2003). The psychological impact of incarceration: Implications for post-prison adjustment. Prisoners once removed: The impact of incarceration and reentry on children, families, and communities, 33, 66.

Haney, C. (2006). The wages of prison overcrowding: Harmful psychological consequences and dysfunctional correctional reactions. Journal of Law and Policy, 22, 265-293. 
Harkins, L., Pritchard, C., Haskayne, D., Watson, A. and A. R. Beech (2011) 'Evaluation of Geese Theatre's Re-Connect Program: Addressing Resettlement Issues in Prison', International Journal of Offender Therapy and Comparative Criminology, 55(4), 546-566.

Hazler, R. J., \& Barwick, N. (2001). The therapeutic environment.

Heyman, B. (2009). Reflecting on a metasynthesis of qualitative articles concerned with pregnant women's decision making about prenatal screening for Down's Syndrome: A commentary on Reid, Sinclair, Barr, Dobbs and Crealey. Social Science and Medicine, 69, 1574-1576. doi:10.1016/j. socscimed.2009.09.011

Hill, R., \& Harris, J. (Eds.). (2011). Principles and practice of group work in addictions. Routledge.

Hilyer, J., \& Mitchell, W. (1979). Effect of systematic physical fitness training combined with counselling on the self-concept of college students. Journal of Counselling Psychology, 26, 427-436.

Holdsworth, E., Bowen, E., Brown, S., \& Howat, D., (2014). Offender engagement in group programs and associations with offender characteristics and treatment factors: A review. Aggression and Violent Behaviour, 19(2), 102-121.

Holman, B., \& Zeidenberg, J. (2006). The dangers of detention: The impact of incarcerating youth in detention and other secure facilities. Justice Policy Institute. Retrieved from: http://www.justicepolicy.org.

Hoskyns, S. (1995). The use of simple ratings scales to assess changes in activity during group music therapy. In: A. Gilroy \& C. Lee (Eds.), Art and music: Therapy and research (pp. 138151). London, England: Routledge. 
Howells, K., Heseltine, K., Sarre, R., Davet, L., \& Day, A. (2004). Correctional offender rehabilitation programs: The national picture in Australia. Canberra: Criminology Research Council. Retrieved from: http://www.aic.gov.au/crc/reports/200203-04.html.

Howells, K., Watt, B., Hall, G., \& Baldwin, S. (1997). Developing programs for violent offenders. Legal and Criminological Psychology, 2, 117-128.

Hughes, J. (2005). Doing the arts justice: A review of research literature, practice and theory. A. Miles, \& A. McLewin (Eds.). London, England: Unit for the Arts and Offenders.

Holdsworth, E., Bowen, E., Brown, S., \& Howat, D. (2014). Offender engagement in group programs and associations with offender characteristics and treatment factors: A review. Aggression and violent behavior, 19(2), 102-121.

Hulley, S., Liebling, A., \& Crewe, B. (2011). Respect in prisons: Prisoners' experiences of respect in public and private sector prisons. Criminology and Criminal Justice, 1748895811423088.

Hurry J., Brazier L., and Wilson A. (2009). Improving the literacy and numeracy of young offenders. In: S. Reder \& J. Brynner (eds.) Tracking adult literacy and numeracy skills: findings from longitudinal research (pp. 261-277). New York: Routledge.

Jewkes, Y. (2005). Men behind bars: "Doing" masculinity as an adaptation to imprisonment. Men and Masculinities Journal, 8, 44-63.

Johnson, H. (2008) 'A Place for Art in Prison: Art as a Tool For Rehabilitation and Management', Southwest Journal of Criminal Justice, 5(2), 100-120.

Justice.gov.uk,. (2015). Offender Behaviour Programmes (OBPs). Retrieved 19 June 2015, from https://www.justice.gov.uk/offenders/before-after-release/obp

Kilgore D. (2001) 'A group learning intervention into how women learn empathy in prison', Adult Education Quarterly, 51(2), 146-164. DOI: 10.1177/07417130122087197

Kormfeld, P.(1997).Cell block visions.Princeton,NJ:Princeton University. 
Labbe', E., Schmidt, N, Babin, J., \& Pharr, M. (2007). Coping with stress: The effectiveness of different types of music. Applied Psychophysiology and Biofeedback, 32, 163-168.

Laub, J. H., \& Sampson, R. J. (2001). Understanding desistance from crime. Crime and justice, 169.

Lawrence, C., \& Andrews, K. (2004). The influence of perceived prison crowding on male inmates' perception of aggressive events. Aggressive Behaviour, 30, 273-283.

Liebling, A. (2002). Suicides in prison. Routledge.

Liebling, A. (2007). Prison suicide and its prevention. In Y, Jewkes (Ed.), Handbook on Prisons (pp. 423-446). Cullompton, Devon: Wilan Publishing.

Liebling, A. (2007). Why prison staff culture matters. In: Byrne J, Taxman F and Hummer D (eds)

The Culture of Prison Violence. Boston, MA: Allyn and Bacon, 105-122.

Liebling, A., \& Arnold, H. (2004). Prisons and Their Moral Performance: A Study of Values, Quality and Prison Life. Oxford: Oxford University Press.

Liebling, A., \& Maruna, S. (Eds.) (2005). The effects of imprisonment. Portland, OR: Willan Publishing.

Liebling, A., \& Price, D. (2001). The Prison Officer. Leyhill: HM Prison Service.

Liebmann, M. (Ed.). (1994). Art therapy with offenders.London: Jessica Kingsley Publishers.

Lipsey, M., Landenberger, N. A., \& Wilson, S. J. (2007). Effects of Cognitive-Behavioral Programs for Criminal Offenders: A Systematic Review.

Maclachlan, K., Hall, S., Tett, L., Crowther, J., \& Edwards, V. (2008). Motivating adult literacies learners to persist, progress and achieve: Literacies learners at risk of non-completion of learning targets.

Markus, H., \& Nurius, P. (1986). Possible selves. American psychologist, 41(9), 954.

Marshall, W. L., Marshall, L. E., Serran, G. A. \& O’Brien, M. D. (2011). Rehabilitating sexual offenders: A strength- based approach. Washington, DC: American Psychological Association. 
Maruna, S. (2010). The great escape: Exploring the rehabilitative dynamics involved in "Changing Tunes.".

Maruna, S., \& LeBel, T. (2010). The desistance paradigm in correctional practice: From programmes to lives. Offender supervision: New directions in theory, research and practice, 65-89.

Maruna, S., Lebel, T. P., Mitchell, N., \& Naples, M. (2004). Pygmalion in the reintegration process: Desistance from crime through the looking glass. Psychology, Crime \& Law, 10(3), 271-281.

McGrath, L., Reavey, P., \& Brown, S. D. (2008). The scenes and spaces of anxiety: Embodied expressions of distress in public and private fora. Emotion, Space and Society, 1(1), 56-64.

McKendy, J. P. (2006). 'I'm very careful about that': narrative and agency of men in prison. Discourse \& Society, 17(4), 473-502. doi: 10.1177/0957926506063128

McNeill, F., Anderson, K., Colvin, S., Overy, K., Sparks, R., and Tett, L. (2011) Inspiring desistance? Arts projects and 'what works?'. Justitiele Verkenningen, 37 (5). pp. 80-101. ISSN $0167-5850$

Meekums, B. (2010). Moving towards evidence for dance movement therapy: Robin Hood in dialogue with the King. The Arts in Psychotherapy, 37(1), 35-41.

Meekums, B., \& Daniel, J. (2011). Arts with offenders: A literature synthesis. The Arts in Psychotherapy, 38(4), 229-238.

Menning, N. (2010). Singing with conviction: New Zealand prisons and Maori populations. International Journal of Community Music, 3(1), 111-120.

Miles, A. and Clarke, R. (2006). The Arts in Criminal Justice: a Study of Research Feasibility,Manchester: Centre for Research on Socio-Cultural Change, University of Manchester.

Mills, J. \& Kroner, D. (2005). An Investigation into the Relationship between Socially Desirable Responding and Offender Self-Report. Psychological Service, 2(1), 70-80. 
Ministry of Justice (2016) Unlocking potential: a review of education in prison, Online:

www.gov.uk/government/publications/unlocking-potentiala- review-of-education-in-prison (last accessed 26.06.2017).

Mossler, K., Fuchs, K., Heldal, T., Karterud, I., Kenner, J., Naesheim, S., \& Gold, C. (2011). The clinical application and relevance of resource-oriented principles in music therapy within and international multicentre study in psychiatry. British Journal of Music Therapy, 25(1), 72-91.

National Criminal Justice Arts Alliance (n.d.). Arts and Criminal Justice. Retrieved 10 October 2016 from https://www.artsincriminaljustice.org.uk/arts-and-criminal-justice/

Newbold, G. (2003). Rehabilitating criminals: It ain't that easy. In J. I. Ross \& S. C. Richards (Eds.) Convict criminology (pp. 247-266). Belmont, CA: Wadsworth/Thomson Learning.

Newman, M., Thompson, C., \& Roberts, A. P. (2006). Helping practitioners understand the contribution of qualitative research to evidence-based practice. Evidence Based Nursing, 9(1), 4-7.

Noblit, G. W., \& Hare, R. D. (1988). Meta-ethnography: Synthesizing qualitative studies (Vol. 11). Sage.

Nugent, B. and Loucks, N. (2011) 'The Arts and Prisoners: Experiences of Creative Rehabilitation.' The Howard Journal of Criminal Justice. Volume 50 (4). Pp. 356-370

Palmer, T. (1995). A profile of correctional effectiveness and new directions for research. Albany, NY: SUNY Press.

Palmer, E., \& Connelly, R. (2005). Depression, hopelessness and suicide ideation among vulnerable prisoners. Criminal Behaviour and Mental Health, 15, 164-170.

Pawson, R., \& Tilley, N. (1994). What works in evaluation research?. British Journal of Criminology, 34(3), 291-306.

Phillips, L. (1996) 'The social impact of the Arts Working Paper 9,' In the Public Interest: Making Art that Makes a Difference in the USA. Stroud Comedia, p. 8. 
Popay, J., Rogers, A., \& Williams, G. (1998). Rationale and standards for the systematic review of qualitative literature in health services research. Qualitative health research, 8(3), 341-351.

Popay, J., Roberts, H., Sowden, A., Petticrew, M., Arai, L., Rodgers, M., ... \& Duffy, S. (2006). Guidance on the conduct of narrative synthesis in systematic reviews. A product from the ESRC methods programme Version, 1, b92.

Schnittker, J., \& John, A. (2007).Enduring stigma: The long-term effects of incarceration on health. Journal of Health and Social Behaviour, 48(2), 115-130.

Shieh, E. (2010). On punishment and music education: Towards a practice for prisons and schools. International Journal of Community Music, 3(1), 19-32.

Sibley, D., \& Van Hoven, B. (2009). The contamination of personal space: boundary construction in a prison environment. Area, 41(2), 198-206.

Silber, L. (2005) 'Bars behind bars: the impact of a women's prison choir on social harmony', Music Education Research, 7(2), 251-271.

Tait, S. (2012). Custody, Care and Staff-Prisoner Relationships. In: B. Crewe \& J. Bennett (eds.), The Prisoner (pp. 13-26). Abingdon: Routledge.

Tangney, J., Stuewig, J., Mashek, D., \& Hastings, M. (2011). Assessing jail inmates' proneness to shame and guilt: Feeling bad about the behavior or the self? Criminal Justice \& Behaviour, 38(7), $71-734$.

Taylor, A. J. W.(1961). A therapeutic group in prison. International Journal of Group Psychotherapy, 11(2), 180-187.

Tett, L., Anderson, K., McNeill, F., Overy, K., \& Sparks, R. (2012). Learning, rehabilitation and the arts in prisons: a Scottish case study. Studies in the Education of Adults, 44(2), 171-185

The Arts Alliance (n.d.) Turning lives around: The arts and the criminal justice system. The role of the arts in rehabilitating offenders. Retrieved 14 March 2014, from http://www.artsalliance.org.uk 
The Prison Arts Coalition (n.d.). Programs. Retrieved from 10 October 2016, from https://theprisonartscoalition.com/programs/

Thomas, J., \& Harden, A. (2008). Methods for the thematic synthesis of qualitative research in systematic reviews. BMC medical research methodology, $8(1), 1$

Thorne, S., Jensen, L., Kearney, M. H., Noblit, G., \& Sandelowski, M. (2004). Qualitative metasynthesis: reflections on methodological orientation and ideological agenda. Qualitative health research, 14(10), 1342-1365.

Timko, C., \& Moos, R. H. (1998). Outcomes of the treatment climate in psychiatric and substance abuse programs. Journal of Clinical Psychology, 54(8), 1137-1150.

Walsh, T. (2006). Is corrections correcting? An examination of prisoner rehabilitation policy and practice in Queensland. Australian and New-Zealand Journal of Criminology, 39, 109-133.

Ward, T., \& Stewart, C. A. (2003). The treatment of sexual offenders: Risk management and good lives. Professional Psychology: Research and Practice, 34, 353-360.

Welsh, B., \& Farrington, D. (2000). Correctional intervention programs and cost-benefit analysis. Criminal Justice \& Behaviour, 27(1), 115-133.

Wilson, J. Q., \& Herrnstein, R. J. (1985). Crime and human nature. New York: Simon \& Schuster.

Winn M. T. and Behizadeh N. (2011) 'The right to be literate: Literacy, Education, and the schoolto-prison pipeline', Review of Research in Education, 35(1), 147-173. DOI: $10.3102 / 0091732 X 10387395$.

Wormith, J. S., Althouse, R., Simpson, M., Reitzel, L. R., Fagan, T. J., \& Morgan, R. D. (2007). The Rehabilitation and Reintegration of Offenders: The Current Landscape and Some Future Directions for Correctional Psychology. Criminal Justice and Behavior, 34(7), 879-892. doi: $10.1177 / 0093854807301552$ 
Scratton, P. (2016). Bearing witness to the 'pains of others': Researching power, violence and resistance in a women's prison. International Journal for Crime, Justice \& Social Democracy, 5(1): 5-20).

Shieh, E. (2010). On punishment and music education: Towards a practice for prisons and schools. International Journal of Community Music, 3(1), 19-32.

Staum, M. J., \& Brotons, M. (2000). The effect of music amplitude on the relaxation response. Journal of Music Therapy, 37(1), 22-39.

Thomas, J., \& Harden, A. (2008). Methods for the thematic synthesis of qualitative research in systematic reviews. BMC medical research methodology, $8(1), 1$.

Uggen, C., Wakefield, S., \& Western, B. (2005). Work and family perspectives on reentry. Prisoner reentry and crime in America, 209-243.

White, J. M. (2001). Music as intervention: a notable endeavor to improve patient outcomes. The Nursing clinics of North America, 36(1), 83-92.

Wilson, D., and M. Logan. 2006.Breaking down walls The good vibrations project in prison Birmingham: Centre for Criminal Justice Policy and Research.

Yochelson, S., \& Samenow, S. (1976). The criminal personality. Vol. 1: A profile for change. New York: Jason Aronson.

Yochelson, S., \& Samenow, W. (1977). The criminal personality, Vol. 2: The change process. New York: Jason Aronson. 


\begin{tabular}{|c|c|c|c|c|c|}
\hline Study & setting & $\begin{array}{l}\text { Partic } \\
\text { ipants }\end{array}$ & $\begin{array}{l}\text { Type of } \\
\text { program } \\
\text { me }\end{array}$ & Design/ Method & Method of Analysis \\
\hline $\begin{array}{l}\text { Digar } \\
\text { d, } \\
\text { Von } \\
\text { Spone } \\
\text { ck \& } \\
\text { Liebli } \\
\text { ng, } \\
2005\end{array}$ & $\begin{array}{l}\text { Contrac } \\
\text { ted } \\
\text { prison }\end{array}$ & $\begin{array}{l}\text { Self- } \\
\text { harmi } \\
\text { ng } \\
\text { femal } \\
\text { e } \\
\text { prison } \\
\text { ers }\end{array}$ & $\begin{array}{l}\text { Percussio } \\
\mathrm{n} \text { music } \\
\text { program } \\
\text { me } \\
\text { (Gamela } \\
\text { n) }\end{array}$ & $\begin{array}{l}\text { Participant observation, } \\
\text { interviews and questionnaires }\end{array}$ & Content Analysis \\
\hline $\begin{array}{l}\text { Maru } \\
\text { na, } \\
2010\end{array}$ & $\begin{array}{l}12 \\
\text { differen } \\
\mathrm{t} \\
\text { prisons }\end{array}$ & $\begin{array}{l}87 \\
\text { male } \\
\text { prison } \\
\text { ers } \\
\text { partici } \\
\text { pating } \\
\text { in the } \\
\text { progra } \\
\text { mme }\end{array}$ & $\begin{array}{l}\text { Program } \\
\text { me using } \\
\text { music } \\
\text { teaching, } \\
\text { rehearsin } \\
\text { g, } \\
\text { recording } \\
\text {, } \\
\text { performa } \\
\text { nce, } \\
\text { improvis } \\
\text { ation and } \\
\text { compositi } \\
\text { on }\end{array}$ & $\begin{array}{l}\text { Written feedback from } \\
\text { participants, observation } \\
\text { notes, focus-group interviews }\end{array}$ & Thematic content analysis \\
\hline $\begin{array}{l}\text { Cox } \\
\& \\
\text { Gelsth } \\
\text { orpe, } \\
2008\end{array}$ & $\begin{array}{l}8 \text { male } \\
\text { prison } \\
\text { establis } \\
\text { hments }\end{array}$ & $\begin{array}{l}71 \\
\text { Partici } \\
\text { pating } \\
\text { male } \\
\text { prison } \\
\text { ers of } \\
\text { varyin } \\
\text { g } \\
\text { senten } \\
\text { ce } \\
\text { length } \\
\text { (rema } \\
\text { nd, }\end{array}$ & $\begin{array}{l}\text { Intense } \\
\text { program } \\
\text { me for } \\
\text { small } \\
\text { groups of } \\
\text { prisoners, } \\
\text { focused } \\
\text { on } \\
\text { creating } \\
\text { music }\end{array}$ & $\begin{array}{l}\text { Field observation, focus } \\
\text { groups, prisoner \& staff } \\
\text { questionnaires, interviews, } \\
\text { analysis of disciplinary and } \\
\text { related prison records }\end{array}$ & $\begin{array}{l}\text { Initiation of various descriptive } \\
\text { statistics and frequencies using an } \\
\text { SPSS software; execution of several } \\
\text { statistical tests using non-parametric } \\
\text { models (the study does not mention } \\
\text { the type of tests) }\end{array}$ \\
\hline
\end{tabular}




\begin{tabular}{|c|c|c|c|c|c|}
\hline & & $\begin{array}{l}\text { short, } \\
\text { mid } \\
\text { and } \\
\text { long } \\
\text { term } \\
\text { senten } \\
\text { ces, } \\
\text { vulner } \\
\text { able } \\
\text { prison } \\
\text { ers). } \\
49 \text { of } \\
\text { the } \\
\text { men } \\
\text { were } \\
\text { follow } \\
\text { ed up. }\end{array}$ & & & \\
\hline $\begin{array}{l}\text { De } \\
\text { Viggi } \\
\text { ani, } \\
\text { MacK } \\
\text { intosh } \\
\& \\
\text { Lang, } \\
2010\end{array}$ & $\begin{array}{l}6 \\
\text { prison } \\
\text { establis } \\
\text { hments } \\
\text {, one of } \\
\text { which } \\
\text { was a } \\
\text { closed } \\
\text { female } \\
\text { prison }\end{array}$ & $\begin{array}{l}80 \\
\text { partici } \\
\text { pants } \\
\text { with a } \\
\text { focus } \\
\text { on } \\
\text { older } \\
\text { prison } \\
\text { ers }\end{array}$ & $\begin{array}{l}\text { Music } \\
\text { education } \\
\text { program } \\
\text { me, } \\
\text { develope } \\
\text { d } \\
\text { specifical } \\
\text { ly to } \\
\text { address } \\
\text { the needs } \\
\text { of older } \\
\text { prisoners }\end{array}$ & $\begin{array}{l}\text { Field notes, participant } \\
\text { observation, semi-structured } \\
\text { interviews, focus-group } \\
\text { interviews }\end{array}$ & $\begin{array}{l}\text { Transcribed verbatim of audio- } \\
\text { recordings were anonymized and } \\
\text { coded }\end{array}$ \\
\hline $\begin{array}{l}\text { Ander } \\
\text { son \& } \\
\text { Overy } \\
, 2010\end{array}$ & $\begin{array}{l}\text { Young } \\
\text { Offend } \\
\text { ers } \\
\text { Instituti } \\
\text { on }\end{array}$ & $\begin{array}{l}14 \\
\text { young } \\
\text { offend } \\
\text { ers }\end{array}$ & $\begin{array}{l}\text { Program } \\
\text { me } \\
\text { focused } \\
\text { on music } \\
\text { education } \\
\text { /creating } \\
\text { music }\end{array}$ & $\begin{array}{l}\text { Structured interviews, } \\
\text { profiling data (behavior } \\
\text { incidents and engagement), } \\
\text { emotion scale, locus of } \\
\text { control of behavior scale, } \\
\text { Rosenberg self-esteem scale, } \\
\text { and dyslexia adult screening } \\
\text { test }\end{array}$ & Not mentioned \\
\hline $\begin{array}{l}\text { Brews } \\
\text { ter, } \\
2010\end{array}$ & $\begin{array}{l}\text { Ex- } \\
\text { offende } \\
\text { rs/ }\end{array}$ & $\begin{array}{l}\text { Ex- } \\
\text { offend } \\
\text { ers, }\end{array}$ & $\begin{array}{l}\text { Music \& } \\
\text { Guitar } \\
\text { program }\end{array}$ & In-depth interviews & Content analysis \\
\hline
\end{tabular}




\begin{tabular}{|c|c|c|c|c|c|}
\hline & $\begin{array}{l}\text { researc } \\
\mathrm{h} \text { was } \\
\text { conduct } \\
\text { ed } \\
\text { outside } \\
\text { the } \\
\text { prison }\end{array}$ & $\begin{array}{l}\text { forme } \\
\text { r } \\
\text { partici } \\
\text { pants } \\
\text { of } \\
\text { music } \\
\text { progra } \\
\text { mme }\end{array}$ & mes & & \\
\hline $\begin{array}{l}\text { Henle } \\
\text { y, } \\
2012\end{array}$ & $\begin{array}{l}\text { Young } \\
\text { Offend } \\
\text { ers } \\
\text { Instituti } \\
\text { on }\end{array}$ & $\begin{array}{l}19 \\
\text { male } \\
\text { partici } \\
\text { pants }\end{array}$ & $\begin{array}{l}\text { Percussio } \\
\text { n music } \\
\text { program } \\
\text { me } \\
\text { (Gamela } \\
\text { n) }\end{array}$ & $\begin{array}{l}\text { Field notes, semi-structured } \\
\text { interviews, questionnaire, } \\
\text { and focus groups }\end{array}$ & $\nabla \sqrt{0}$ \\
\hline $\begin{array}{l}\text { Henle } \\
\text { y, } \\
\text { Caulfi } \\
\text { eld, } \\
\text { Wilso } \\
\text { n \& } \\
\text { Wilki } \\
\text { nson, } \\
2013\end{array}$ & $\begin{array}{l}\text { Various } \\
\text { male } \\
\text { prison } \\
\text { establis } \\
\text { hments, } \\
\text { one } \\
\text { female } \\
\text { and a } \\
\text { follow } \\
\text { up of } \\
\text { ex- } \\
\text { offende } \\
\text { rs who } \\
\text { had } \\
\text { particip } \\
\text { ated in } \\
\text { the } \\
\text { progra } \\
\text { mme }\end{array}$ & $\begin{array}{l}\text { Forme } \\
\text { r } \\
\text { partici } \\
\text { pants } \\
(7), \\
\text { new } \\
\text { cohort } \\
\text { of } \\
\text { partici } \\
\text { pants } \\
(8), \\
\text { ex- } \\
\text { offend } \\
\text { ers in } \\
\text { the } \\
\text { comm } \\
\text { unity } \\
\text { (7), } \\
\text { femal } \\
\text { e } \\
\text { partici } \\
\text { pants } \\
\text { (10) }\end{array}$ & $\begin{array}{l}\text { Percussio } \\
\text { n music } \\
\text { program } \\
\text { me } \\
\text { (Gamela } \\
\text { n) }\end{array}$ & $\begin{array}{l}\text { Participatory Action } \\
\text { research. Interviews with } \\
\text { participants, prison staff, } \\
\text { analysis of disciplinary and } \\
\text { other records in order to } \\
\text { assess behavior change, } \\
\text { 'emotion scale' }\end{array}$ & Thematic analysis \\
\hline $\begin{array}{l}\text { Twani } \\
, 2011\end{array}$ & $\begin{array}{l}\text { Male } \\
\text { prison } \\
\text { establis }\end{array}$ & $\begin{array}{l}153 \\
\text { partici } \\
\text { pants }\end{array}$ & $\begin{array}{l}\text { Music } \\
\text { program } \\
\text { me }\end{array}$ & $\begin{array}{l}\text { Field reports, DVD } \\
\text { recordings, photographs, } \\
\text { evaluation reports, and }\end{array}$ & $\begin{array}{l}\text { Thematic content analysis (data } \\
\text { categorization and analytic } \\
\text { reflection). }\end{array}$ \\
\hline
\end{tabular}




\begin{tabular}{|c|c|c|c|c|c|}
\hline & hment & $\begin{array}{l}\text { (both } \\
\text { staff } \\
\text { and } \\
\text { prison } \\
\text { ers) }\end{array}$ & $\begin{array}{l}\text { including } \\
\text { education } \\
\text { on how } \\
\text { to play } \\
\text { instrume } \\
\text { nts and } \\
\text { choir } \\
\text { singing }\end{array}$ & journal entries. & \\
\hline $\begin{array}{l}\text { Bilby, } \\
\text { Caulfi } \\
\text { eld \& } \\
\text { Ridle } \\
\text { y, } \\
2013\end{array}$ & $\begin{array}{l}4 \\
\text { crimina } \\
1 \text { justice } \\
\text { settings } \\
\text { : high } \\
\text { security } \\
\text { male } \\
\text { prison, } \\
\text { young } \\
\text { offende } \\
\text { rs in the } \\
\text { commu } \\
\text { nity, } \\
\text { resettle } \\
\text { ment } \\
\text { (open) } \\
\text { prison, } \\
\text { closed } \\
\text { female } \\
\text { prison }\end{array}$ & $\begin{array}{l}11 \\
\text { male } \\
\text { prison } \\
\text { ers } \\
\text { from a } \\
\text { high } \\
\text { securit } \\
\text { y } \\
\text { prison } \\
\text {,7 } \\
\text { males } \\
\text { prison } \\
\text { ers } \\
\text { from } \\
\text { an } \\
\text { open } \\
\text { prison } \\
\text {, eight } \\
\text { adult } \\
\text { femal } \\
\text { es } \\
\text { within } \\
\text { a } \\
\text { wome } \\
\text { n's } \\
\text { prison } \\
\text {, four } \\
\text { young } \\
\text { people } \\
\text { who } \\
\text { were } \\
\text { subiec }\end{array}$ & $\begin{array}{l}\text { Music } \\
\text { and } \\
\text { deejaying } \\
\text { project } \\
\text { for } \\
\text { young } \\
\text { offenders } \\
\text {, art } \\
\text { classes } \\
\text { for } \\
\text { personali } \\
\text { ty } \\
\text { disordere } \\
\text { d } \\
\text { offenders } \\
\text { in high } \\
\text { security } \\
\text { prison, a } \\
\text { creative } \\
\text { writing } \\
\text { project } \\
\text { from a } \\
\text { female } \\
\text { closed } \\
\text { prison, a } \\
\text { project } \\
\text { for } \\
\text { creating } \\
\text { music }\end{array}$ & $\begin{array}{l}\text { Interviews and participants' } \\
\text { written work and evaluations }\end{array}$ & Thematic content analysis \\
\hline
\end{tabular}




\begin{tabular}{|c|c|c|c|c|c|}
\hline & & $\begin{array}{l}\mathrm{t} \text { to } \\
\text { comm } \\
\text { unity } \\
\text { senten } \\
\text { ces or } \\
\text { bail } \\
\text { condit } \\
\text { ions }\end{array}$ & & & \\
\hline $\begin{array}{l}\text { Caulfi } \\
\text { eld, } \\
\text { Wilso } \\
\text { n \& } \\
\text { Wilki } \\
\text { nson, } \\
2009\end{array}$ & $\begin{array}{l}\text { Therap } \\
\text { eutic } \\
\text { prison } \\
\& \\
\text { commu } \\
\text { nity }\end{array}$ & $\begin{array}{l}26 \\
\text { men } \\
\text { and } \\
\text { wome } \\
\mathrm{n} \text { who } \\
\text { had } \\
\text { previo } \\
\text { usly } \\
\text { partici } \\
\text { pated } \\
\text { in the } \\
\text { progra } \\
\text { mme }\end{array}$ & $\begin{array}{l}\text { Percussio } \\
\mathrm{n} \text { music } \\
\text { program } \\
\text { me } \\
\text { (Gamela } \\
\text { n) }\end{array}$ & $\begin{array}{l}\text { interviews, adjudication } \\
\text { reports and OASys records, } \\
\text { and interviews with prison } \\
\text { staff, emotion scale, face to } \\
\text { face or telephone interviews } \\
\text { with released participants }\end{array}$ & Not mentioned \\
\hline $\begin{array}{l}\text { Wind } \\
\text { er, } \\
\text { Sperli } \\
\text { ng, } \\
\text { Elliott } \\
\text {, } \\
\text { Lieve } \\
\text { sley, } \\
\text { Faulk } \\
\text { ner \& } \\
\text { Blagd } \\
\text { en, } \\
2015\end{array}$ & $\begin{array}{l}\text { One } \\
\text { UK sex } \\
\text { offende } \\
\text { r prison }\end{array}$ & $\begin{array}{l}51 \\
\text { partici } \\
\text { pants } \\
\text { (the } \\
\text { quanti } \\
\text { tative } \\
\text { part of } \\
\text { the } \\
\text { study) } \\
5 \\
\text { partici } \\
\text { pants } \\
\text { (qualit } \\
\text { ative } \\
\text { part of } \\
\text { the } \\
\text { study) }\end{array}$ & $\begin{array}{l}\text { Good } \\
\text { vibration } \\
\mathrm{s} \\
\text { worksho } \\
\text { ps - } \\
\text { Percussio } \\
\text { n music } \\
\text { program } \\
\text { me } \\
\text { (Gamela } \\
\text { n) }\end{array}$ & $\begin{array}{l}\text { (Quantitative part) - } \\
\text { Dissemination of: (a) } \\
\text { The Corrections Victoria } \\
\text { Treatment Readiness Scale ( } \\
\text { CVTRS) (b) The University } \\
\text { of } \\
\text { Rhode Island Change Assess } \\
\text { ment (URICA) } \\
\text { (Qualitative part)-semi- } \\
\text { structured interviews }\end{array}$ & $\begin{array}{l}\text { (Quantitative part) } \\
\text { Data were inputted into Excel and im } \\
\text { ported into SPSSv22 for analysis. } \\
\text { A series of } 2 \text { X } 2 \text { Mixed } \\
\text { ANOVAS. } \\
\text { (Qualitative part) - Thematic } \\
\text { analysis }\end{array}$ \\
\hline
\end{tabular}




\footnotetext{
' The Risk-Need-Responsivity Model (RNR) is applied in prison programmes worldwide. The basic principle behind it is risk reduction and management, and its popularity is based on the fact that it is a cost-effective method that can be applied to large groups of prisoners. The risk principle addresses the fact that offender treatments should be offered according to risk; high risk offenders should receive the most intensive treatment available, compared with offenders identified as low risk. The need principle states that effective therapies must primarily address offenders' criminogenic needs. Lastly, the responsivity principle addresses the need for offender treatment therapies to match an offender's learning abilities (Andrews \& Bonta, 1998; Ward, Vess, \& Collie, 2006, Gannon \& Ward, 2014).

ii The 'Unlocking potential: a Review of education in prison' review report, published on 18 May 2016 highlights the need for a reform in educational practices in prisons, suggests a more individually tailored approach: 'The current mechanism for funding prison education should be revised so that Governors and/or providers can design a curriculum that meets the individual needs and Personal Learning Plan of each prisoner for whom they are responsible', granting greater autonomy to prison governors over how they run their establishments.
} 